\title{
Biology and distribution of hemichordates (Enteropneusta) with emphasis on Harrimaniidae and description of Protoglossus bocki sp. nov. from Scandinavia
}

\author{
Tomas Cedhagen • Hans G. Hansson
}

Received: 29 August 2011/Revised: 29 June 2012/ Accepted: 14 July 2012/Published online: 14 September 2012

(C) Springer-Verlag and AWI 2012

\begin{abstract}
A new species of the genus Protoglossus is described from the west coast of the Scandinavian Peninsula. It lives buried in clay bottoms below the halocline where the salinity is at least 33-34 psu. Body small, estimated maximal length $1.5 \mathrm{~cm}$. Collar broader than long, with a forward inclination. The thickest part is the collar region where it can be up to $1 \mathrm{~mm}$ in diameter. Proboscis colouration light pink to golden yellow; collar white with transversal yellow bands; branchial, hepatic and intestinal regions translucent pale yellow to golden yellow; brown intestine visible through the body wall. Proboscis groove extends through posterior half of proboscis. Nine to 17 pairs of gill openings, the size of the posteriormost successively smaller. It differs from the other European species, Protoglossus koehleri, in colouration, smaller size, fewer gill openings, body shape and proportions. It was sequenced (18S rRNA gene) and clustered within the family Harrimaniidae, with Saxipendium as its closest relative.
\end{abstract}

Keywords Hemichordata - Enteropneusta . Harrimaniidae · Protoglossus bocki n.sp. · Scandinavian Peninsula

Communicated by H.-D. Franke.

Hans G. Hansson: Deceased.

T. Cedhagen $(\bowtie)$

Department of Biological Sciences, Section of Marine Ecology, Aarhus University, Building 1135, Ole Worms allé 1,

8000 Aarhus C, Denmark

e-mail: cedhagen@biology.au.dk

H. G. Hansson

Tjärnö Marine Biological Laboratory, University of Gothenburg, 45296 Strömstad, Sweden

\section{Introduction}

Enteropneusts are poorly known in the Skagerrak-Kattegat area. Von Willemoes-Suhm (1871) described Harrimania kupfferi (originally as Balanoglossus Kupfferi) from Øresund, Denmark. This species was later reported from the Gullmarfjord area by Théel (1908) and subsequent authors. A second species, Glossobalanus marginatus Meek 1922, was obtained from Sweden by Lindroth (1941) and Silén (1950). The marine fauna of Sweden from the Norwegian border to Öresund was investigated from 1925 to 1938. Altogether, 440 stations were sampled, but there are no reports on enteropneusts (Hubendick et al. 1971). The conventional sieving and sorting methods have probably destroyed all the fragile enteropneusts.

The new species has been sampled off the west coast of Sweden since the earlier parts of the twentieth century. Collectors were Dr. Gunnar Gustafson (1891-1988) at Kristineberg Marinezoological Station, Fiskebäckskil (Royal Swedish Academy of Sciences), and Prof. Sixten Bock (1884-1946) at the Swedish Museum of Natural History, Stockholm. In August 1927, when looking for other animals, Sixten Bock discovered a small enteropneust that he found to be very different from Harrimania. He first believed that it was a specimen of Protoglossus koehleri (Caullery and Mesnil 1900), which was only found on the French Atlantic coast at that time, but later understood that it was an undescribed species of the same genus. The small size and fragility of the animal explains why this species has been overlooked. Bock made extensive studies of it in the field station and histological studies in the laboratory. He intended to describe it, but this work was interrupted by his sudden death. Parts of a manuscript draft, including photographs and drawings, are deposited in the archive of the Swedish Museum of Natural History. The present 
Table 1 Material of Protoglossus bocki n. sp. Swedish Museum of Natural History, Stockholm (SMNH), Natural History Museum, Göteborg, Sweden (GNM)

\begin{tabular}{|c|c|c|c|c|}
\hline $\begin{array}{l}\text { Material } \\
\text { number }\end{array}$ & $\begin{array}{l}\text { Collection } \\
\text { number }\end{array}$ & Locality, date & Leg./Det. & Notes \\
\hline 1 & SMNH-32 & $\begin{array}{l}\text { Sweden, Bohuslän, Gullmarfjord area, } \\
\text { Humlesäcken. 1927-08-16 }\end{array}$ & S. Bock & $\begin{array}{l}\text { Fixed in Bouin's fluid. Specimen in } \\
\text { the wet collection and as } \\
\text { microscopic slides }\end{array}$ \\
\hline 2 & SMNH-36 & $\begin{array}{l}\text { Sweden, Bohuslän, Gullmarfjord area, } \\
\text { near Flatholmen. 1931-05-14 }\end{array}$ & S. Bock & $\begin{array}{l}\text { Fixed in sublimat. Specimen as } \\
\text { microscopic slides only }\end{array}$ \\
\hline 3 & SMNH-37 & $\begin{array}{l}\text { Sweden, Bohuslän, Gullmarfjord area, } \\
\text { Humlesäcken, } 40 \text { m depth. 1931-05-15. }\end{array}$ & S. Bock & $\begin{array}{l}\text { Fixed in } 5 \% \text { alcohol and cold } 90 \% \\
\text { sublimat solution. Specimen in the } \\
\text { wet collection and as microscopic } \\
\text { slides }\end{array}$ \\
\hline 4 & SMNH-40 & $\begin{array}{l}\text { Sweden, Bohuslän, Gullmarfjord area, } \\
\text { near Flatholmen and in Humlesäcken. } \\
\text { 1931-11-17 }\end{array}$ & S. Bock & $\begin{array}{l}\text { Specimen in the wet collection. } \\
\text { Holotype }\end{array}$ \\
\hline 5 & SMNH-41 & $\begin{array}{l}\text { Sweden, Bohuslän, Gullmarfjord area, } \\
\text { near Flatholmen and in Humlesäcken. } \\
\text { 1931-11-17 }\end{array}$ & S. Bock & $\begin{array}{l}\text { Fixed in } 5 \% \text { alcohol and Bouin's } \\
\text { fluid. Specimen in the wet } \\
\text { collection }\end{array}$ \\
\hline 6 & SMNH-42 & $\begin{array}{l}\text { Sweden, Bohuslän, Gullmarfjord area, } \\
\text { Tova. 1931-11-18 }\end{array}$ & S. Bock & $\begin{array}{l}\text { Fixed in } 5 \% \text { alcohol and Bouin's } \\
\text { fluid. Specimen as microscopic } \\
\text { slides only }\end{array}$ \\
\hline 7 & SMNH-43 & $\begin{array}{l}\text { Sweden, Bohuslän, Gullmarfjord area, } \\
\text { Tova. 1931-11-20 }\end{array}$ & S. Bock & $\begin{array}{l}\text { Anaesthetized in } \mathrm{MgCl} 2 \text { and fixed in } \\
\text { sublimat. Specimen in the wet } \\
\text { collection and as microscopic slides }\end{array}$ \\
\hline 8 & SMNH-45 & $\begin{array}{l}\text { Sweden, Bohuslän, Gullmarfjord area, } \\
\text { Tova. 1931-11-25 }\end{array}$ & S. Bock & $\begin{array}{l}\text { Fixed in formalin. Specimen in the } \\
\text { wet collection }\end{array}$ \\
\hline 9 & SMNH-46 & $\begin{array}{l}\text { Sweden, Bohuslän, Gullmarfjord area, } \\
\text { Tova. 1931-11-25 }\end{array}$ & S. Bock & $\begin{array}{l}\text { Fixed in } 5 \% \text { alcohol and hot } \\
\text { sublimat solution. Specimen in the } \\
\text { wet collection }\end{array}$ \\
\hline 10 & SMNH-47 & $\begin{array}{l}\text { Sweden, Bohuslän, Gullmarfjord area, } \\
\text { Tova. 1931-11-25 }\end{array}$ & S. Bock & $\begin{array}{l}\text { Fixed in } 5 \% \text { alcohol and formalin. } \\
\text { Specimen in the wet collection and } \\
\text { as microscopic slides }\end{array}$ \\
\hline 11 & SMNH-48 & $\begin{array}{l}\text { Sweden, Bohuslän, Gullmarfjord area, } \\
\text { near Flatholmen, } 40 \text { m depth. 1932-08-11 }\end{array}$ & S. Bock & $\begin{array}{l}\text { Fixed in Bouin's fluid. Specimen as } \\
\text { microscopic slides only }\end{array}$ \\
\hline 12 & SMNH-49 & $\begin{array}{l}\text { Sweden, Bohuslän, Gullmarfjord area, } \\
\text { Humlesäcken, } 30 \text { m depth }\end{array}$ & S. Bock & $\begin{array}{l}\text { Specimen in the wet collection and as } \\
\text { microscopic slides }\end{array}$ \\
\hline 13 & SMNH-53 & $\begin{array}{l}\text { Norway, Oslofjorden, Drøbak, near } \\
\text { Degerud depth and Gråøy, 150-100 m } \\
\text { depth. 1936-07-1-2 }\end{array}$ & Leg. C. Dons, Det. S. Bock & $\begin{array}{l}\text { Fixed in Bouin's solution. Specimen } \\
\text { in the wet collection }\end{array}$ \\
\hline 14 & SMNH-54 & $\begin{array}{l}\text { Norway, Trondhjem, Vikleiret, 15-20 m } \\
\text { depth. 1936-07-13 }\end{array}$ & Leg. C. Dons, Det. S. Bock & $\begin{array}{l}\text { Specimen as microscopic slides only. } \\
\text { The slide is labelled } 1932 \text { instead of } \\
1936\end{array}$ \\
\hline 15 & SMNH-57 & $\begin{array}{l}\text { Norway, Skagerak, Vestfold, } 7 \mathrm{~km} \mathrm{~S} \text { of } \\
\text { Tvesten, } 58^{\circ} 52^{\prime} \mathrm{N}, 009^{\circ} 57^{\prime} \mathrm{E}, 130-150 \mathrm{~m} \\
\text { depth }\end{array}$ & $\begin{array}{l}\text { Sixten Bock's Skagerak } \\
\text { Expedition } 1937 \text { Station } \\
\text { 28.7.A. Det. S. Bock }\end{array}$ & Specimen in the wet collection \\
\hline 16 & SMNH-59 & $\begin{array}{l}\text { Norway, Oslofjorden, Drøbak, } \\
\text { Hakungspollen,. 1938-08-08 }\end{array}$ & S. Bock & Specimen in the wet collection \\
\hline 17 & SMNH-60 & $\begin{array}{l}\text { Norway, Oslofjorden, Drøbak, } \\
\text { Hakungspollen, } 12 \text { m depth. 1938-08-08 }\end{array}$ & S. Bock & $\begin{array}{l}\text { Fixed in formalin. Specimen in the } \\
\text { wet collection }\end{array}$ \\
\hline 18 & SMNH-61 & $\begin{array}{l}\text { Norway, Oslofjorden, Drøbak, } \\
\text { Hakungspollen,. 1938-08-08 }\end{array}$ & S. Bock & $\begin{array}{l}\text { Fixed in sublimat, picric acid and } \\
\text { formalin. Specimen in the wet } \\
\text { collection }\end{array}$ \\
\hline 19 & & $\begin{array}{l}\text { Sweden, Skagerak, sledge sample Start: } \\
58^{\circ} 28.012^{\prime \prime} \mathrm{N} ; 10^{\circ} 48.901^{\prime} \mathrm{E} \text {. End: } \\
58^{\circ} 28.141^{\prime} \mathrm{N} ; 10^{\circ} 49.675^{\prime} \mathrm{E} \text {. Depth: } \\
103-119.2006-06-05\end{array}$ & $\begin{array}{l}\text { Leg. R/V Arne Tiselius, } \\
\text { ArtDatabanken, Det. Hans G. } \\
\text { Hansson }\end{array}$ & Figure 2 in this publication \\
\hline
\end{tabular}


Table 1 continued

\begin{tabular}{|c|c|c|c|c|}
\hline $\begin{array}{l}\text { Material } \\
\text { number }\end{array}$ & $\begin{array}{l}\text { Collection } \\
\text { number }\end{array}$ & Locality, date & Leg./Det. & Notes \\
\hline 20 & GNM- & $\begin{array}{l}\text { Sweden, Skagerak,. Sledge sample Start: } \\
58^{\circ} 06,526^{\prime} \mathrm{N} ; 11^{\circ} 11,740^{\prime} \mathrm{E} \text {, end: } 58^{\circ} \\
06,322^{\prime} \mathrm{N} ; 11^{\circ} 11,169^{\prime} \mathrm{S} \text {. Depth: } 68-72 \mathrm{~m} \text {. } \\
2008-08-20\end{array}$ & $\begin{array}{l}\text { Leg. R/V Arne Tiselius, } \\
\text { ArtDatabanken, Running no: } \\
\text { 228. St. nr: SK68 bsk1. Det. } \\
\text { T. Cedhagen }\end{array}$ & \\
\hline 21 & & Sweden, Skagerak, Koster area, Aug. 2009 & $\begin{array}{l}\text { Leg. M. Strand, Det. } \\
\text { T. Cedhagen }\end{array}$ & $\begin{array}{l}\text { Figure } 1 \text { in this publication. A } \\
\text { fragment of this individual was } \\
\text { sequenced at SMNH }\end{array}$ \\
\hline
\end{tabular}

Fig. 1 Protoglossus bocki n.sp. Creeping individual where the proboscis shape with dorsal groove, collar colouration, dorsal ridge and gill openings is visible. Photograph: Christopher Reisborg

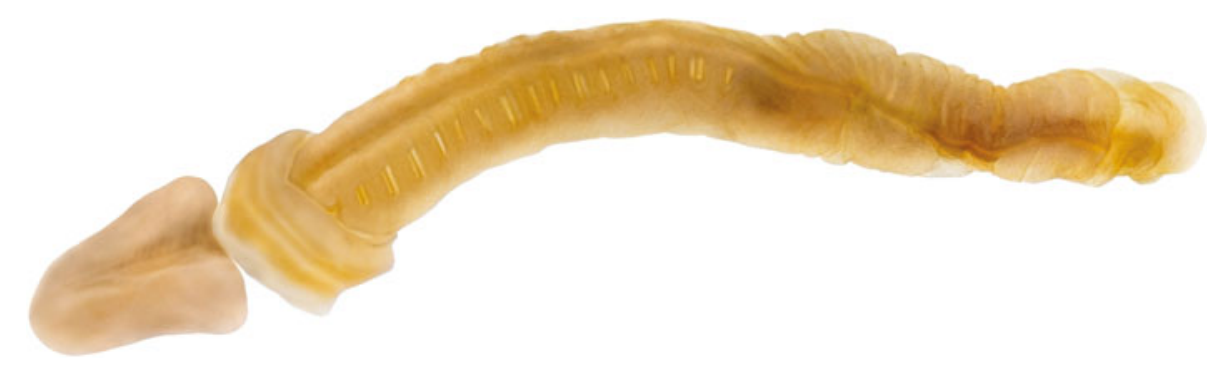

description is based on Sixten Bock's results supplemented with new material.

Silén (1950) used material of this species, collected by G. Gustafson, for comparative purposes. He referred to it as Protoglossus sp. Silén did not formally describe the species because his focus was on the nervous system of another enteropneust species. He wrote that the nervous system of the tiny Protoglossus sp. was very difficult to observe, but supported his general conclusions based on his studies of the other much larger species, Glossobalanus marginatus, collected in the same area (Silén 1950). Åke Franzén (1956) used two individuals of the Protoglossus species for the studies of sperm morphology. The species is also included in the discussion by Franzén et al. (1985), but mainly as a reference to Franzén (1956). Hansson (2009) and Lundin et al. (2009) used Sixten Bock's tentative

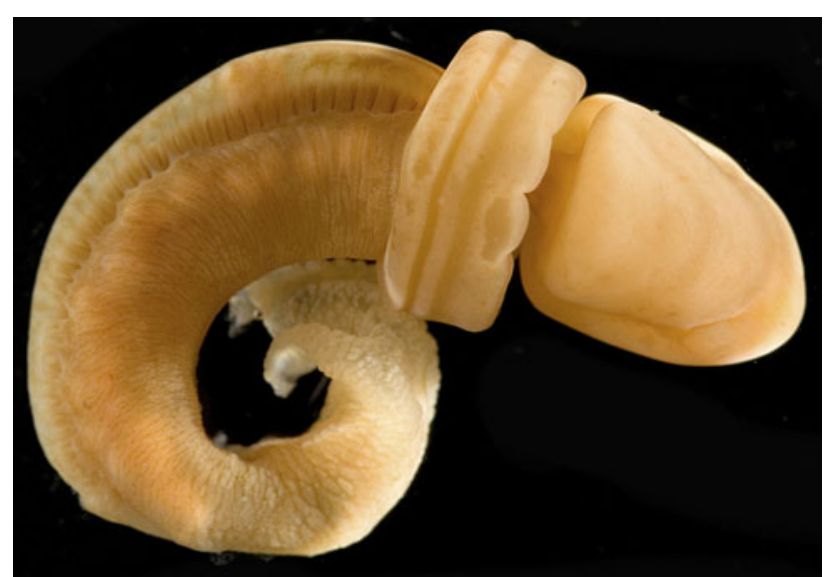

Fig. 2 Protoglossus bocki n.sp. Living but unhealthy individual with relaxed proboscis musculature. Photograph: Fredrik Pleijel
Fig. 3 Protoglossus bocki n.sp. Fixed individual. Lateral view seen from right. Scale bar $1 \mathrm{~mm}$. Drawing: Sven Ekblom 


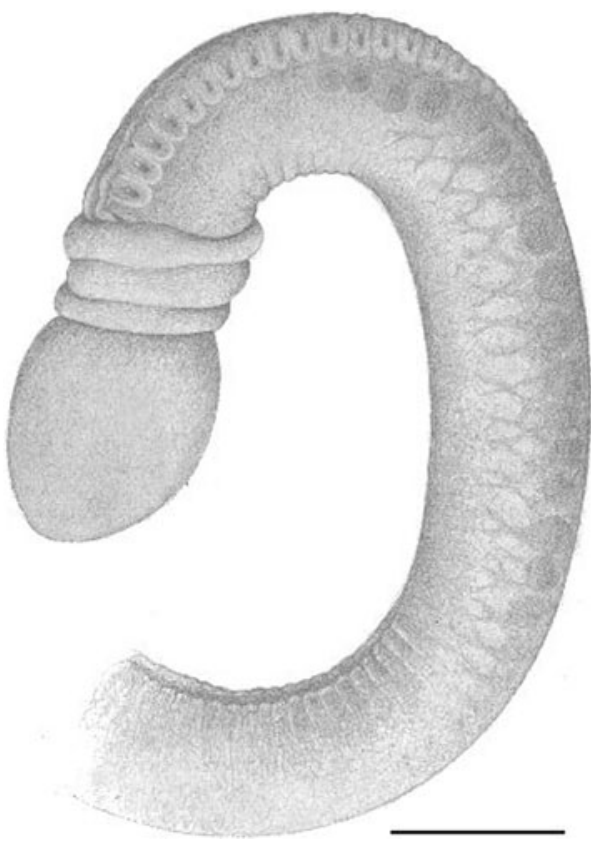

Fig. 4 Protoglossus bocki n.sp. Fixed individual. Lateral view seen from left side. Scale bar $1 \mathrm{~mm}$. Drawing: Sven Ekblom

manuscript name Protoglossus simplex (nomen nudum) for it. Also, Prof. Bertil Akesson observed the species in Kristineberg Marine Zoological Station in the 1950s or 1960s (pers. comm.).

\section{Materials and methods}

Sixten Bock collected eight individuals between 27 July and the end of August 1927 in Humlesäcken, in the outer area of Gullmarsfjorden, Sweden. He sampled several times after the first findings, but in most cases without result. Sediment was usually collected by the use of an Agassiz trawl at that time. The conventional sediment-sieving method could not be used because of the fragility of the animal. Mud was therefore filled in buckets and covered with just a little water, left for some time and frequently inspected.

Bock anaesthetized the animals by the addition of ethyl urethane to the sea water until a strength of $3 \%$, with a subsequent treatment with $5 \%$ alcohol in sea water. Several specimens were sectioned for microscopy. The internal structures of some whole mounts of individuals were made visible after clearing by the use of aniseed oil.

A small number of additional specimens have been collected in Skagerrak and Kattegat in the beginning of the twenty-first century, mainly as a result of the activities run by the Swedish Taxonomy Project. A few of them have been photographed and preserved in alcohol in order to allow molecular studies. Sequencing (18S rRNA genes) of the new species Protoglossus bocki as well as Harrimania
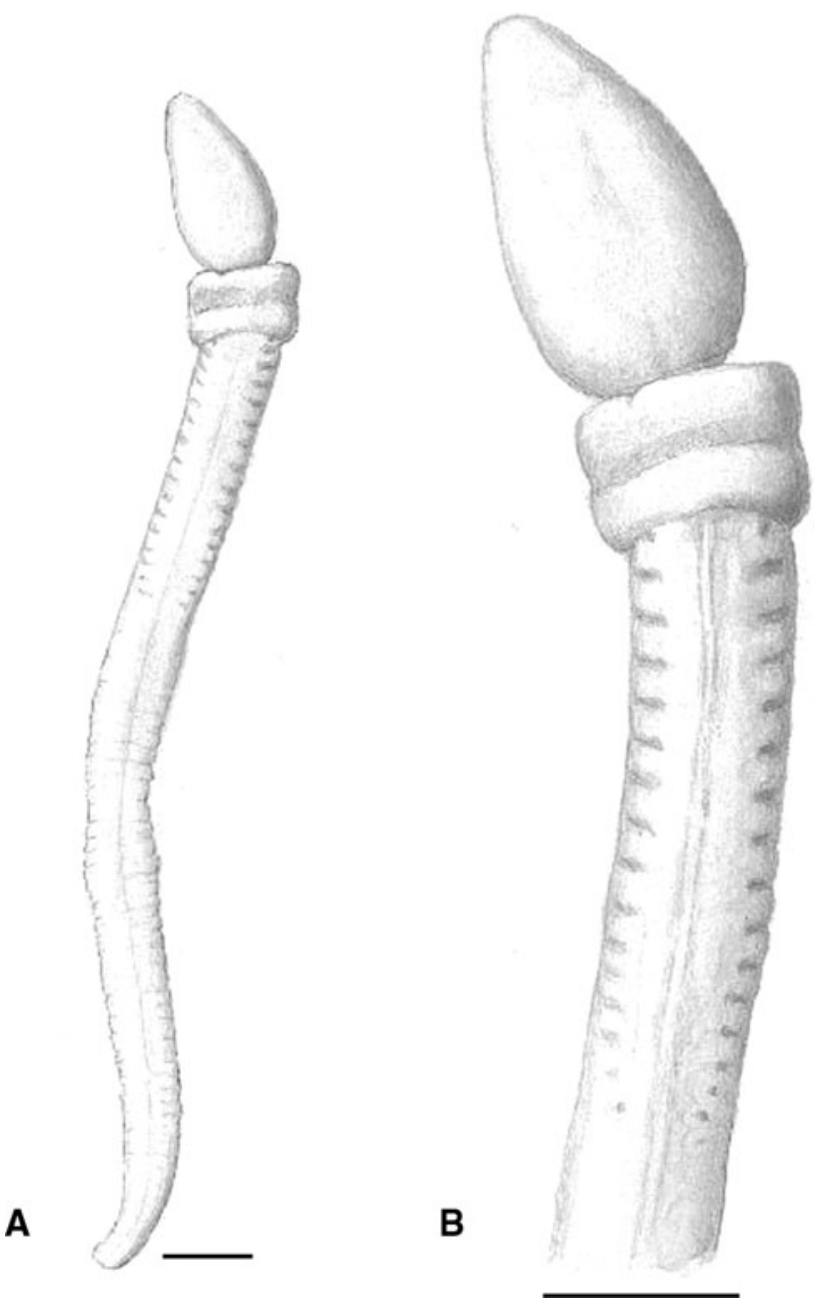

Fig. 5 Protoglossus bocki $n$.sp. Fixed individual showing the median dorsal ridge. Scale bars $1 \mathrm{~mm}$. Drawing: Sven Ekblom

kupfferi was made at the molecular biology laboratory, Swedish Museum of Natural History. The alignment of the sequences was done manually using Seaview (Gouy et al. 2010). Phylogenetic analysis was performed using maximum likelihood (PhyML) programmes as implemented in Seaview. The support for internal branches was inferred using 100 bootstrap replicates.

Specimens are deposited in the collections of the Swedish Museum of Natural History, Stockholm (NRM), and the Natural History Museum, Gothenburg (GNM), both in Sweden, and summarized in Table 1. Sixten Bock identified all materials sampled by himself, and some of these samples were later verified to belong to Protoglossus by Cyril Burdon-Jones during his stay at the NRM in 1998.

\section{Taxonomy}

The position of the group Hemichordata has been disputed (Gerhart et al. 2005), but is now regarded as a sister group 
Fig. 6 Protoglossus bocki n.sp. Fixed individual, dorsal view. Scale bar $1 \mathrm{~mm}$. Drawing: Sven Ekblom

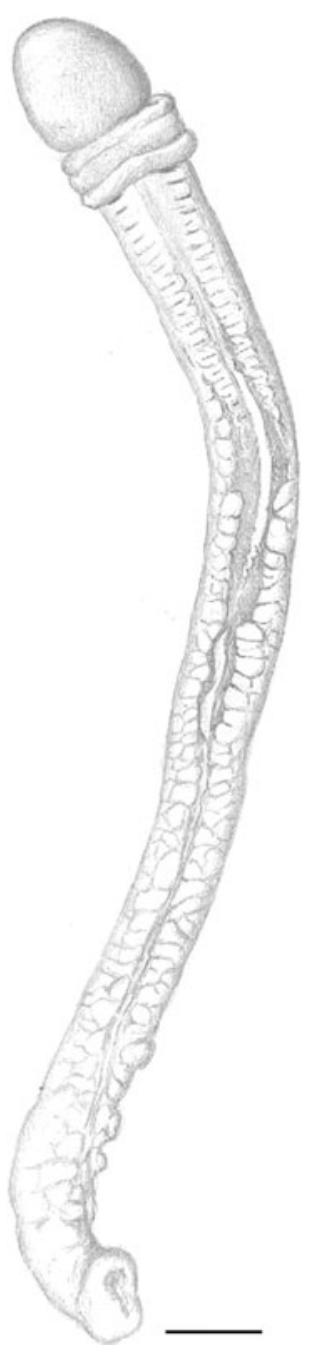

of Echinodermata. Both are together called Ambulacraria, which is the sister group of the remaining deuterostomesthe chordates (Hejnol et al. 2009).

The hemichordate group Enteropneusta has recently been revised by the use of morphological and molecular methods (Cameron 2005; Cannon et al. 2009). The family Harrimaniidae, to which the new species belongs, is revised by Deland et al. (2010). Detailed information on morphology and histology of enteropneusts has been summarized by van der Horst (1939), Hyman (1959) and Benito and Pardos (1997).

\section{Protoglossus van der Horst, 1935}

Type species: Protoglossus koehleri (Caullery and Mesnil, 1900). Substitute name for Protobalanus (preocc.) (Caullery and Mesnil, 1904).

Diagnosis: Genus characterized by short conical proboscis with deep posterior dorsal groove and conspicuous
Fig. 7 Protoglossus bocki n.sp. Fixed individual, dorsal view. Scale bar $1 \mathrm{~mm}$. Drawing: M. Cederström

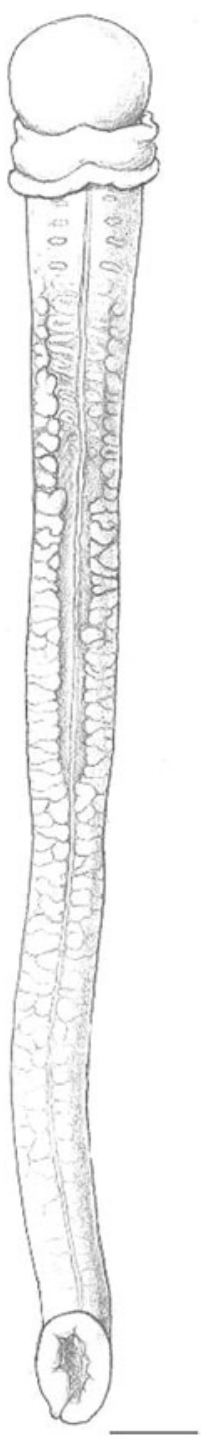

shaped pre-oral ciliary organ (Gonzalez and Cameron 2009). Longitudinal musculature of proboscis radial, its paired dorsal gonads not prominent. Protoglossus considered having simplest arrangement of enteropneust body cavities in lacking peribuccal cavities and having rudimentary or no perihaemal cavities (Burdon-Jones 1956). Left proboscis pore present, along with dorsal and ventral mesenteries in proboscis and collar. Cornua of skeleton extending to posterior margin of collar, forming parabuccal ridges on each side of buccal cavity (Deland et al. 2010).

Remarks: Three species of Protoglossus have been described (Cameron 2010): Protoglossus koehleri (Caullery and Mesnil, 1900); Protoglossus graveolens Giray and King, 1996; and Protoglossus mackiei Deland, Cameron, Rao, Ritter and Bullock, 2010.

Protoglossus bocki n. sp. Figures 1, 2, 3, 4, 5, 6, 7, 8, 9, 10, $11,12,13,14,15,16,17,18$ and 19. 


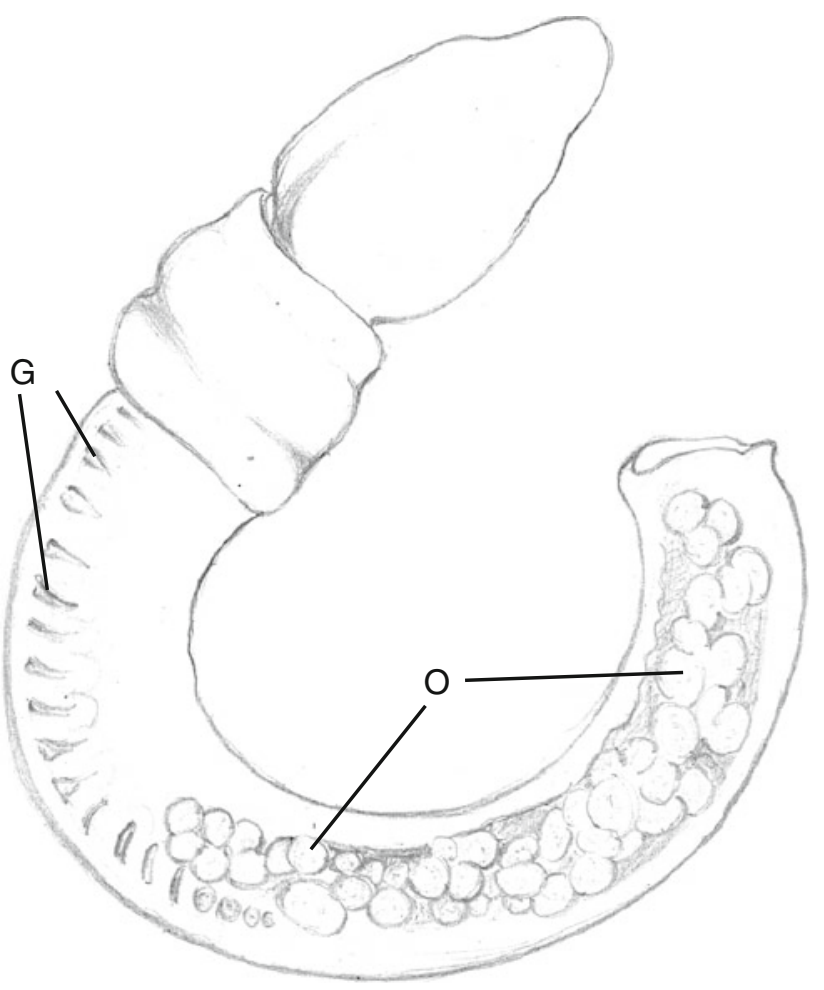

Fig. 8 Protoglossus bocki n.sp. Drawing of living female, showing the position of ovaries with oocytes $(O)$ and gill openings $(G)$. Drawing: Esther Löfgren

Synonymy: Protoglossus sp. Silén 1950, pp. 149, 151, 153; Franzén 1956, pp. 443, 450, 461; Franzén et al. 1985. p. 303.

Protoglossus simplex. Hansson 2009, p. 313.

Protoglossus "simplex". Lundin et al. 2009, p. 41.

Material: Specimens in the collections of NRM and GNM (Table 1).

Etymology: We dedicate this species in honour of Professor Sixten Bock (1884-1946), who discovered the species and made extensive studies of it. Sixten Bock was the godfather of one of the authors (HGH).

Diagnosis: Body small, estimated maximal length $1.5 \mathrm{~cm}$. Collar broader than long. Proboscis colouration light pink to golden yellow; collar white with transversal yellow bands; branchial, hepatic and intestinal regions translucent pale yellow to golden yellow; brown intestine visible through the body wall. Proboscis groove extends through posterior half of proboscis. Proboscis coelom large (1/3 to $1 / 2$ of proboscis diameter). Stomochord extends through $1 / 4-1 / 3$ of proboscis. The proboscis skeleton is well developed in its anterior part. It has a cup-shaped anterior part, and dorsal and lateral wing-like projections that support the stomochord and axial complex. Its two

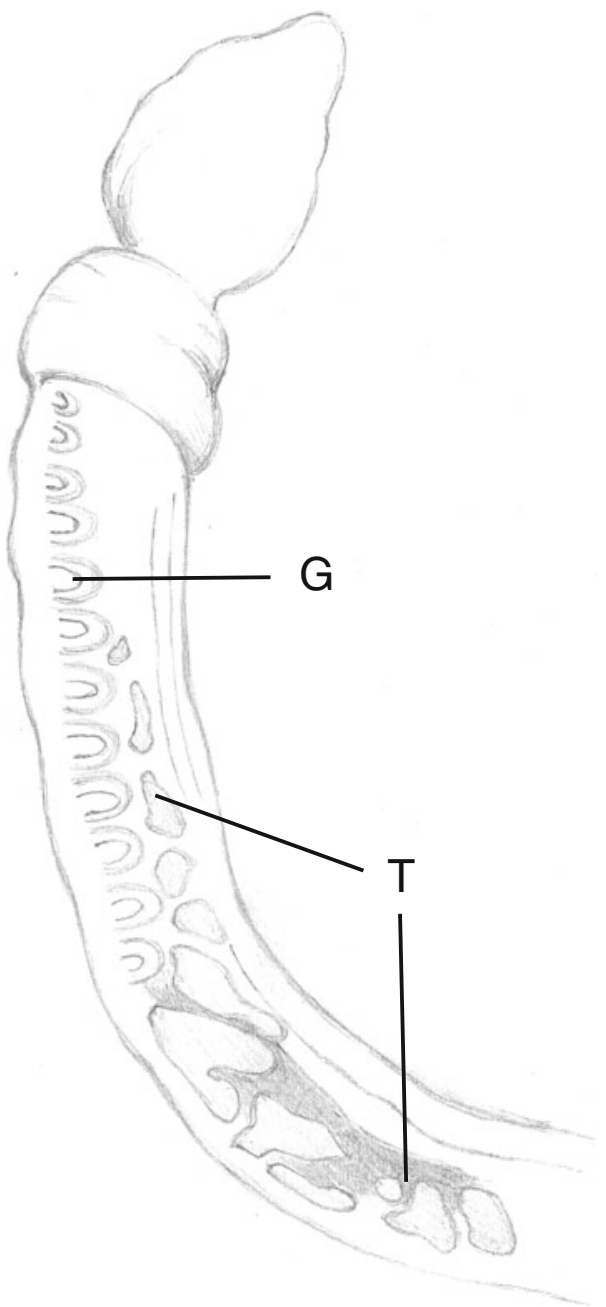

Fig. 9 Protoglossus bocki n.sp. Drawing of living male, showing the position of testes $(T)$ and gill openings $(G)$. Drawing: Esther Löfgren

crura extend posteriorly into the collar around the oesophagus and slightly curve and taper. The left and right collar coeloms (mesocoels) are completely separated by dorsal and ventral septa (mesenteria). Nine to 17 pairs of gill openings, the size of the posteriormost successively smaller. The branchial skeleton is weakly developed and has no synapticles.

Deposition of type material: Holotype: SMNH-40.

\section{Description}

External features

Proboscis The proboscis in living individuals is tongueshaped with the ability of dorsoventral flattening. It can dorsally be depressed into a longitudinal deep groove (Figs. 1, 8, 9). The groove is successively widening on the 


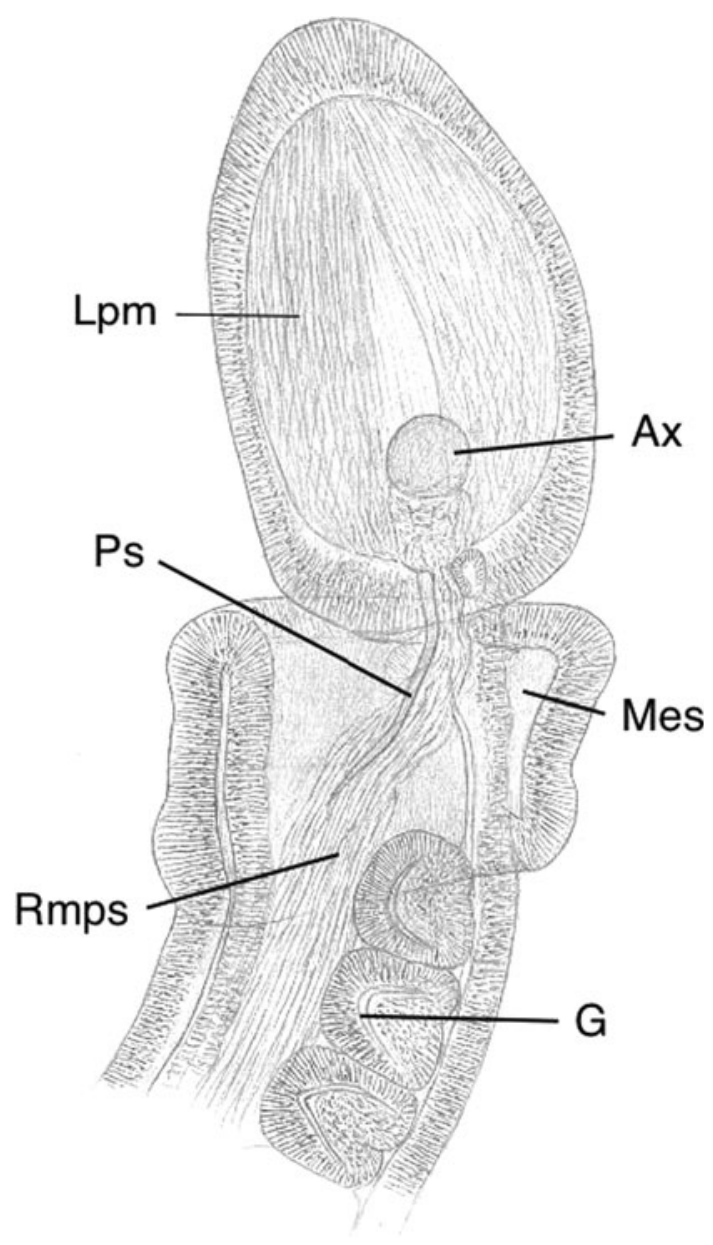

Fig. 10 Protoglossus bocki n.sp. Fixed individual made transparent in oil. Scale bar $100 \mu \mathrm{m}$. Drawing: Sven Ekblom. Ps proboscis skeleton, $A x$ axial complex, $G$ gill opening, Lpm longitudinal proboscis musculature, Mes mesocoel, Rmps retractor musculature of proboscis skeleton posterior side of the proboscis and leads to the flattening of its ventral side. The proboscis is 2-2.5 times longer than the length of the collar. Proboscis elongated, slightly conical or even round in anaesthetized and fixed individuals (Figs. 3, 6, 7, 10). A basal sheath exists posterior to the proboscis stalk.

Collar The collar is broader than long. Its anterior rim in living individuals is smooth or just very slightly curled (Figs. 1, 2). The collar has a slight forward inclination seen in actively creeping individuals (Fig. 1) as well as in some of the fixed ones in lateral view (Figs. 8, 10). The collar groove is a conspicuous transversal depression around the collar (Figs. 11, 12). The posterior part of the operculum is smooth and often covers the anteriormost gill opening.

Trunk The gill region is about two times as long as the proboscis length and has 9-17 dorsolateral pairs of elongated transversal gill openings. However, the individual on Fig. 2 could possibly have a few more pairs of gill openings, but this has been impossible to check (as well as the exact size of this individual). A median dorsal ridge exists along the entire trunk (Figs. 1, 5, 7). Lateral gonads are located in the posterior third to half of the branchial region and posteriorly (Figs. 2, 8, 9, 17). There is a tendency towards genital dorsolateral ridges along the trunk, but they are not very prominent.

Size Protoglossus bocki It is smaller than any other species of acorn worm. No specimens are complete, so it is impossible to give the total length.

The thickest part is the collar region that can reach $1 \mathrm{~mm}$ in diameter. The longest part of an individual is less than $1 \mathrm{~cm}$, and such pieces contain not only the gill, but

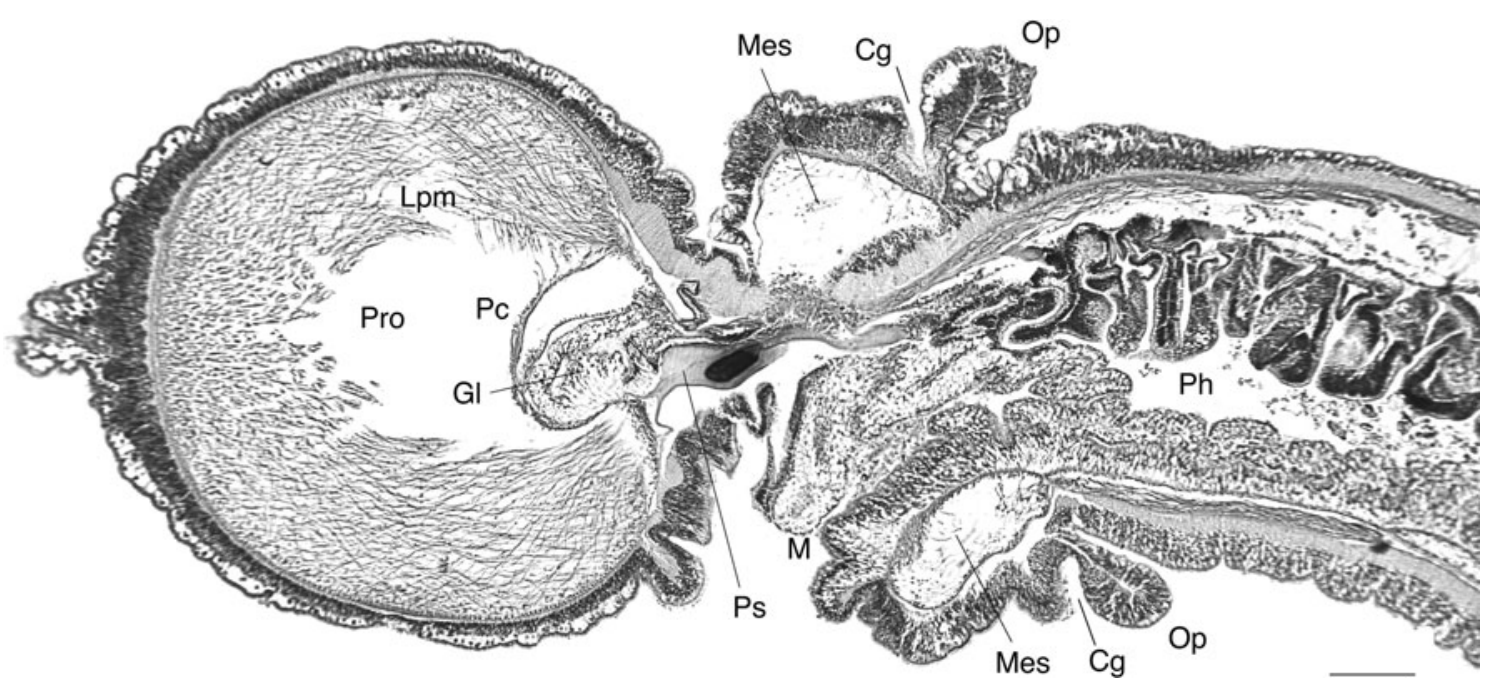

Fig. 11 Protoglossus bocki n.sp. Longitudinal section through the anterior part of an individual. Cg collar groove, Gl glomerulus, $\mathrm{Lpm}$ longitudinal proboscis musculature, $M$ mouth, Mes mesocoel, $O p$ operculum, $P c$ pericardium, $P h$ pharynx, Pro protocoel, $P s$ proboscis skeleton 


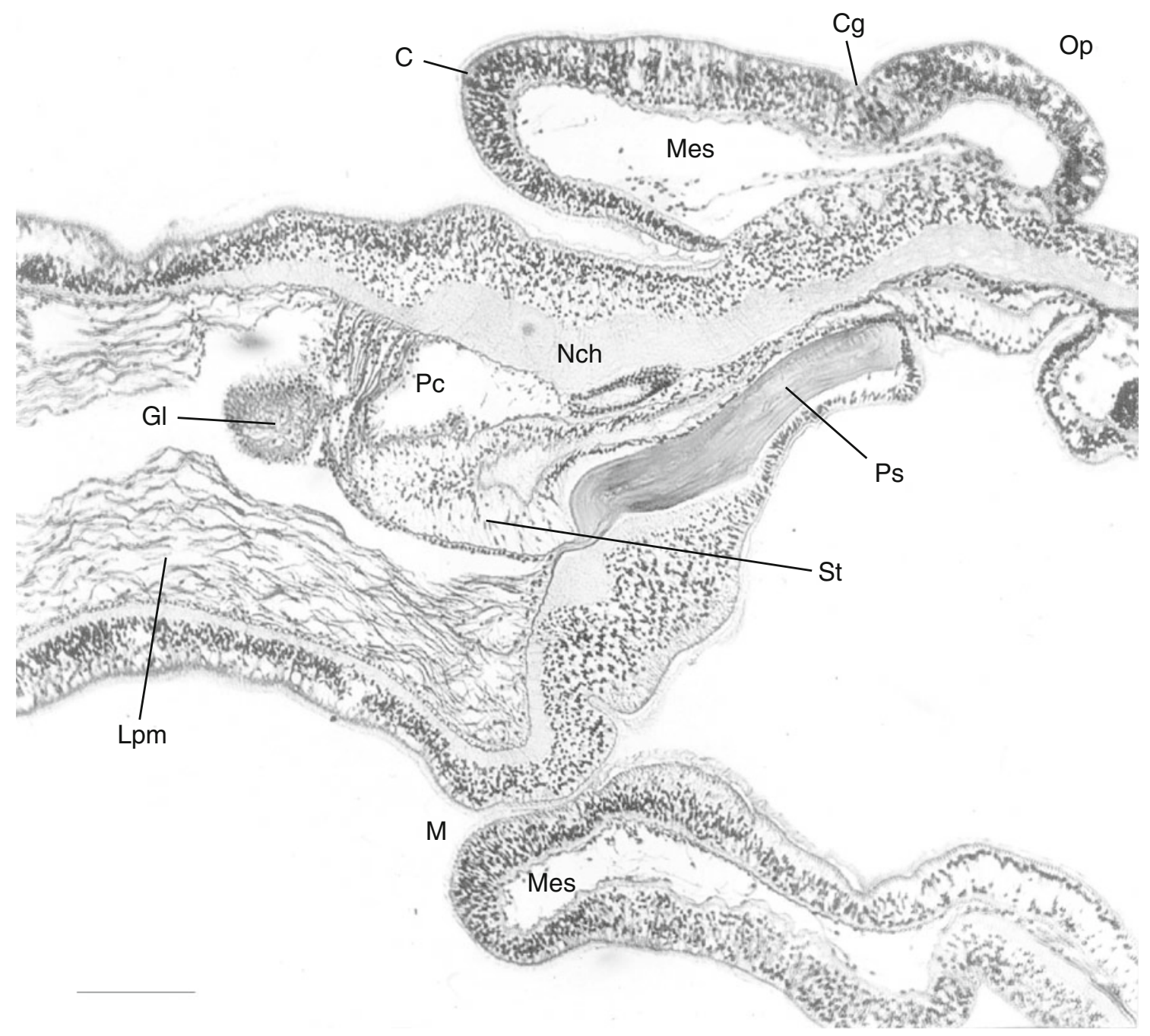

Fig. 12 Protoglossus bocki n.sp. Longitudinal section through the collar and posterior part of the proboscis. Scale bar $100 \mu \mathrm{m}$. Photograph: Sixten Bock. $C$ collar, $C g$ collar groove, $G l$ glomerulus,

also the genital region. The total length can therefore be estimated to about one and a half centimetre.

Colour of living individuals The colour of the proboscis is uniformly light pink to golden yellow (Figs. 1, 2). The anterior rim of the collar is whitish (Figs. 1, 2, 3, 4, 5, 6, 7, $8,9)$. Two slightly darker yellow transversal bands exist around the collar; the posterior of them coincides with the narrow circular depression around the collar, the so-called collar groove. The posterior part of the collar, the operculum, is whitish (Figs. 1, 2, 3, 4, 5, 6, 7, 8, 9). The trunk colour is uniformly light brownish yellow to golden yellow. The mucus gland tissue around the gill openings is slightly lighter yellow than the surrounding body wall. The intestine looks brown through the body wall (Fig. 1). The rose ovaries or white testes can be seen through the body wall (Figs. 2, 8, 9).
Lpm longitudinal proboscis musculature, $M$ mouth, Mes mesocoel, $N c h$ neurochord, $O p$ operculum, $P c$ pericardium, $P s$ proboscis skeleton, St stomochord

Internal features

Proboscis The proboscis is covered by a thick glandular and ciliated epithelium. Its musculature is well developed (Figs. 10, 11). The circular muscle fibre layer is thinner than the nerve fibre layer (Fig. 13). The nerve fibre layer of the proboscis is thickened middorsally (Fig. 13). There is a tendency towards a radial arrangement of the fibres in the longitudinal muscle layer. It is stronger developed laterally than dorsally, and its internal distribution seen in cross section coincides with the shape of the dorsal groove in creeping individuals (Figs. 1, 13).

The new species has a fairly wide protocoel around the heart and axial complex (Fig. 13). It extends to the anterior part of the proboscis and has a well-developed ventral mesenterium (septum). There is no dorsal mesenterium as 
Fig. 13 Protoglossus bocki n.sp. Cross section of the posterior part of the proboscis through the axial complex. Scale bar $100 \mu \mathrm{m}$. Photograph: Sixten Bock. $\mathrm{Cml}$ circular muscle layer, $D g$ dorsal groove, Dnt dorsal nerve thickening, Gce glandular and ciliated epithelium, $G l$ glomerulus, $H$ heart (blood sinus), Lpm longitudinal proboscis musculature, $N f$ nerve fibre layer, $P c$ pericardium, Pro protocoel, St stomochord, Stl stomochord lumen, $\mathrm{Vm}$ ventral mesenterium

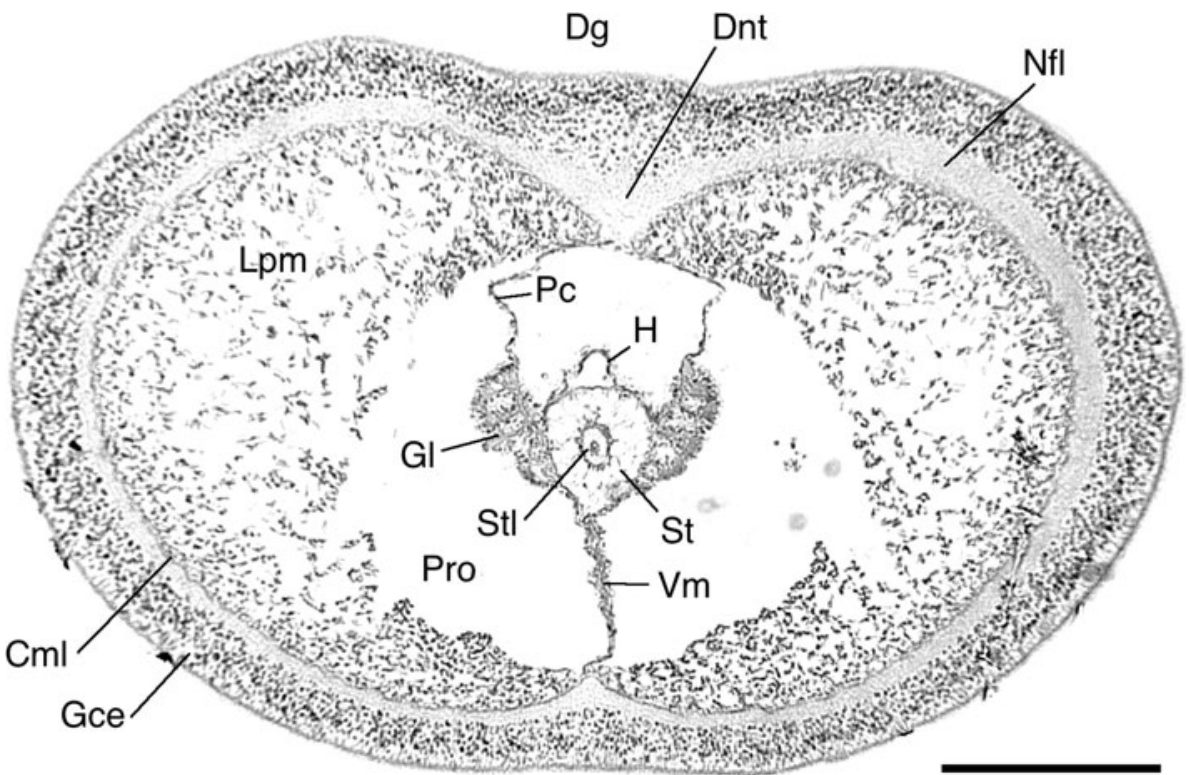

the pericardium is attached directly towards the dorsal nerve thickening. The protocoel is curved towards the single external opening on the left side.

The axial complex (Figs. 10, 11, 12, 13) consists of a large pericardium dorsally attached under the dorsal nerve thickening. It covers the cardiac vesicle, also called heart or blood sinus, which, in turn, is supported by the stomochord, which has a longitudinal lumen along the centre of its axis. The stomochord lacks ventral caecum and extends along the axial complex (Fig. 12). The glomerulus consists of a folded system of vessels, but its organization is simple because of the small size (Fig. 13).

The proboscis skeleton is well developed in its anterior part. It has dorsal and lateral wing-like projections, clearly visible in cross section (Fig. 14), that support the stomochord and axial complex behind the glomerulus. Its two crura extend posteriorly into the collar and slightly curve and taper (Fig. 10). Two coelomic cavities fill the proboscis neck.

Collar Peripharyngeal cavities are lacking, and the perihaemal coelom cavities extend only slightly into the collar region. The collar has a large coelomic cavity (mesocoel), completely divided by well-developed dorsal and ventral septa. The coelomopores from the mesocoel are large and open in the anterior, reduced gill chambers. Two peribuccal coelome diverticules are present.

The crura of the proboscis skeleton extend to the posterior part of the collar and partly surround the mouth cavity. They project slightly laterally and ventrally. The proboscis skeleton retractor musculature forms lateral longitudinal muscle bands (Fig. 10) that are strong, but the other musculature is weakly developed. The collar region is completely separated from the body coelom (metacoel) by a strong septum. A neuropore could not be observed, but lacunae in the dorsal nerve cord exist.

Trunk The trunk region has strongly developed ventral longitudinal muscles, which extend far upwards along the sides of the body (Figs. 15, 16). The contraction of this musculature is usually causing a ventral shrinking of the animals during fixation. There is a pair of small dorsal muscle bands and prominent dorsal and ventral nerve chords (Figs. 15, 16).

The gill intestine, at least in its middle parts, considerably exceeds the hepatic intestine in extent (Fig. 12). The gill pockets are simple and well developed. They are up to $400 \mu \mathrm{m}$ in length, which is half of the body thickness (Fig. 15, 16) and consists of 9-17 pairs. The gill skeleton is weakly developed, but at least, the branchial bars are prominent (Fig. 16). Large numbers of mucus producing glands surround the outer gill openings (Figs. 1, 16). They are elongated, placed transversely, and generally built up by large, sack-shaped cell bodies.

The anterior parts of the gonads extend into the gill region. The ovaries overlap only the posterior part (Fig. 8), but the testes may overlap more than half of the gill region (Figs. 2, 9). The gonads are dorsolateral and up to $400 \mu \mathrm{m}$ in diameter and contain several yolk-rich oocytes, up to $250 \mu \mathrm{m}$ in diameter (Fig. 17).

\section{Remarks}

Sixten Bock noted that $P$. bocki has a characteristic "medicine smell", and Burdon-Jones (1956) wrote that P. koehleri has a smell resembling iodoform, a kind of 

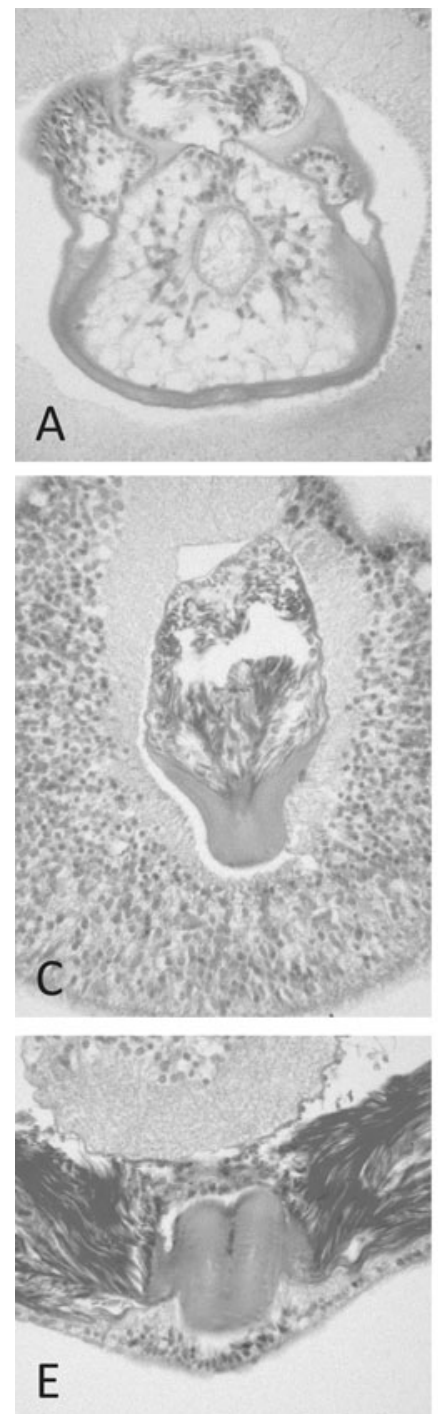
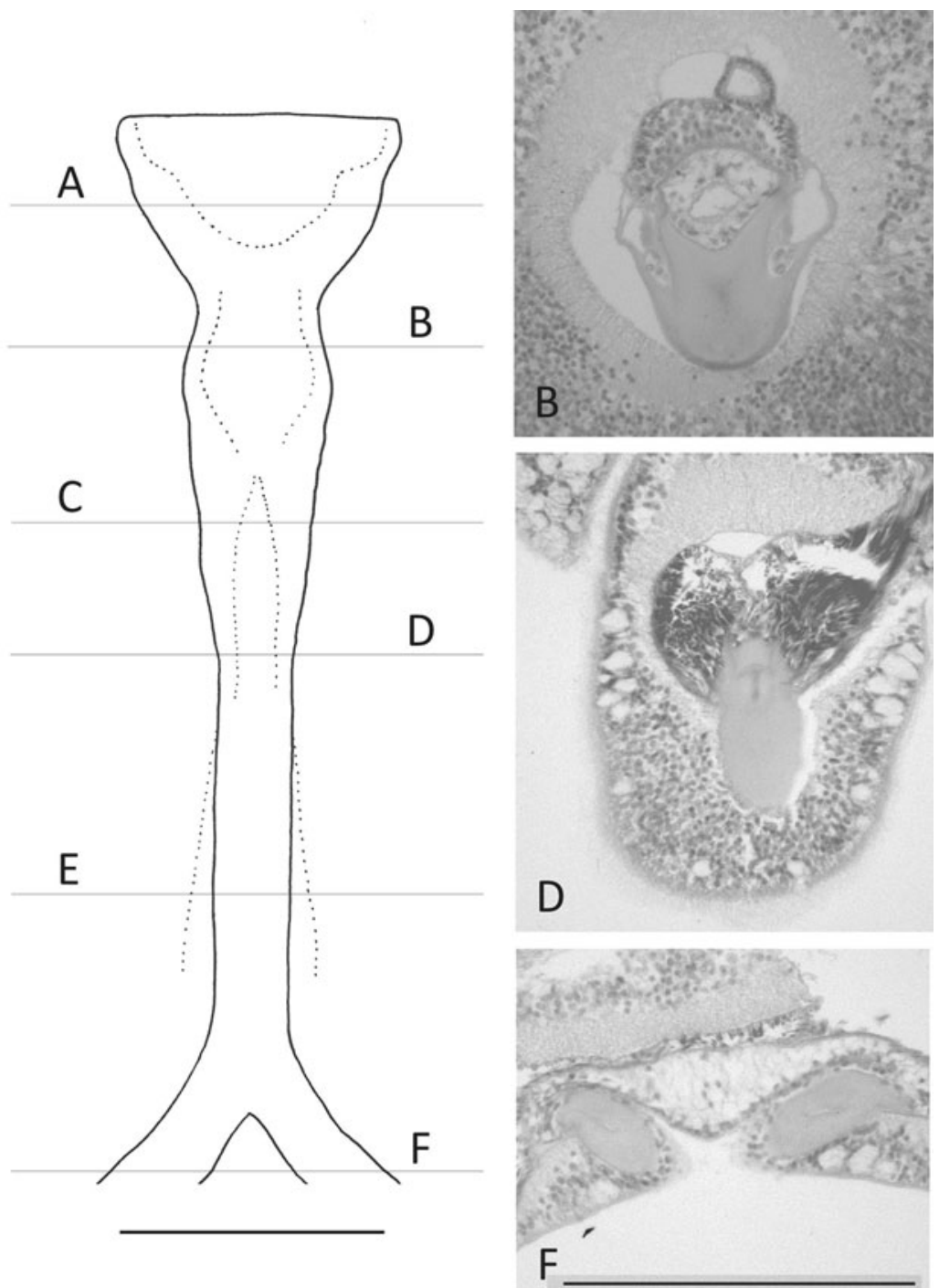

Fig. 14 Protoglossus bocki n.sp. Anterior part of the proboscis skeleton reconstructed from serial sections. The positions of representative cross sections $(A-F)$ are indicated by horizontal lines. Scale bars $100 \mu \mathrm{m}$

Fig. 15 Protoglossus bocki n.sp. Cross section through the gill region. Scale bar $100 \mu \mathrm{m}$. $B p$ branchial pore, $B s$ branchial sac, Dnc dorsal nerve chord, $P h l$ pharynx lumen, $V n c$ ventral nerve chord

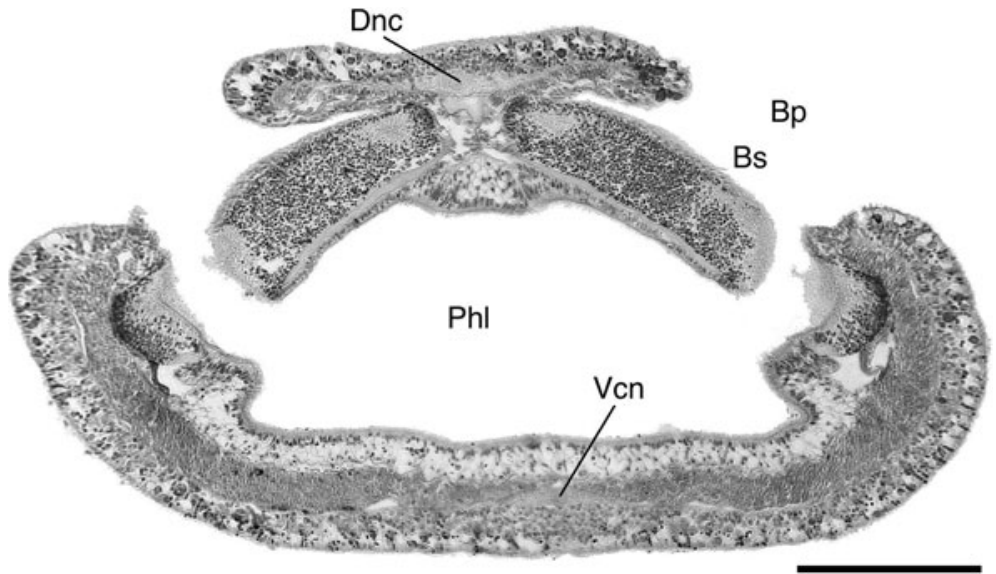


halogenated disinfectant used at his time. Similarly, smelling bromophenolic or haloorganic compounds have been found in P. graveolens (Giray and King 1996, 1997) and $P$. mackiei (Deland et al. 2010).

\section{Observations on living individuals made by Sixten Bock}

Protoglossus bocki lives buried in soft mud and quickly hides by the use of its proboscis. When digging, the proboscis is elongated and flattened a little, and its tip is pointed. During movements, the extended stalk of the proboscis is fully visible (Figs. 3, 4, 5). Also, the collar is extensible, and its form can change. The anterior rim of the collar is very slightly curled, but its posterior part is flatter or thickening. Large amounts of mucus are produced in this region and transported backwards. Contraction waves move along the body (opisthosoma) and support the

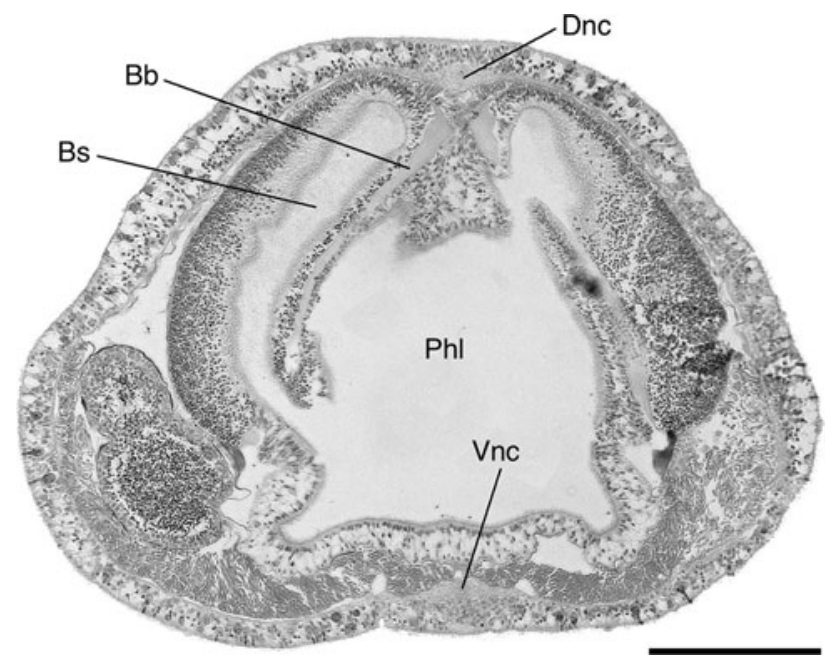

Fig. 16 Protoglossus bocki n.sp. Cross section through the gill region. Scale bar $100 \mu \mathrm{m}$. Bb branchial bar, Bs branchial sac, Dnc dorsal nerve chord, $P h l$ pharynx lumen, $V n c$ ventral nerve chord digging movements of the proboscis. The ciliary movements on the epithelium are very active and transport sediment particles and mucus backwards along the body. Its mucus production stabilizes the sediment around its burrow into a canal. The proboscis was sometimes extended near the sediment surface, but the animal very quickly retracted into this canal if disturbed, for example, during attempts to catch it. Even touching the water surface could be a disturbance that caused it to retract into its burrow.

The animal is extremely fragile and breaks easily into pieces. It is even more fragile than Harrimania kupfferi. The tissues in both species are very easily damaged. They are in this respect also very sensitive to an increased temperature.

Protoglossus bocki can hardly survive in a water-filled glass jar without any sediment, like many other worms from fine-sediment bottoms. It is, however, possible to keep them alive in mud and at lower temperature. Increased temperature has a very detrimental effect, particularly in the absence of mud.

Distribution It is found in open Skagerrak and middle and northern parts of Bohuslän on the west coast of Sweden and also in Oslofjorden and Trondheimsfjorden, Norway.

Sixten Bock collected most of his material in Humlesäcken and Flatholmsrännan near the mouth of Gullmarsfjorden, Swedish west coast. He reported it to live hidden in clay bottom at a water depth of at least 30-40 m. We have, in 2010, sampled the same localities near the mouth of Gullmarsfjorden where Bock obtained his material, but without success. We only found shell gravel, a type of substrate that seems to be unsuitable for the species.

\section{Comparison with the other species of Protoglossus}

Distribution, habitat and selected external and internal characters of diagnostic value within the genus
Fig. 17 Protoglossus bocki n.sp. Cross section showing oocyte bundles on the lateral sides of the intestine. Scale bar $100 \mu \mathrm{m}$. Photograph: Sixten Bock. I intestine, Ltm longitudinal trunk musculature, Met metacoel, $O$ oocytes in ovary, $V b v$ ventral blood vessel, $V n c$ ventral nerve chord

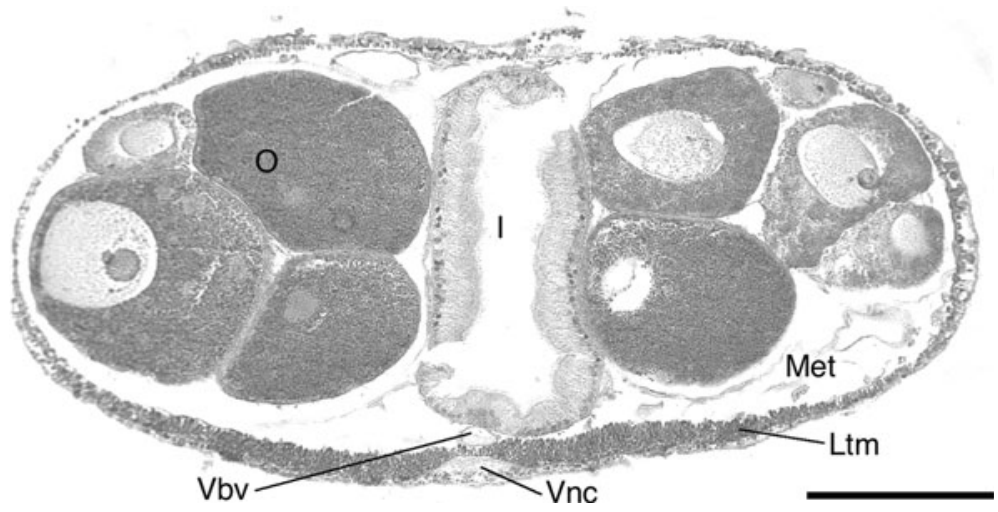




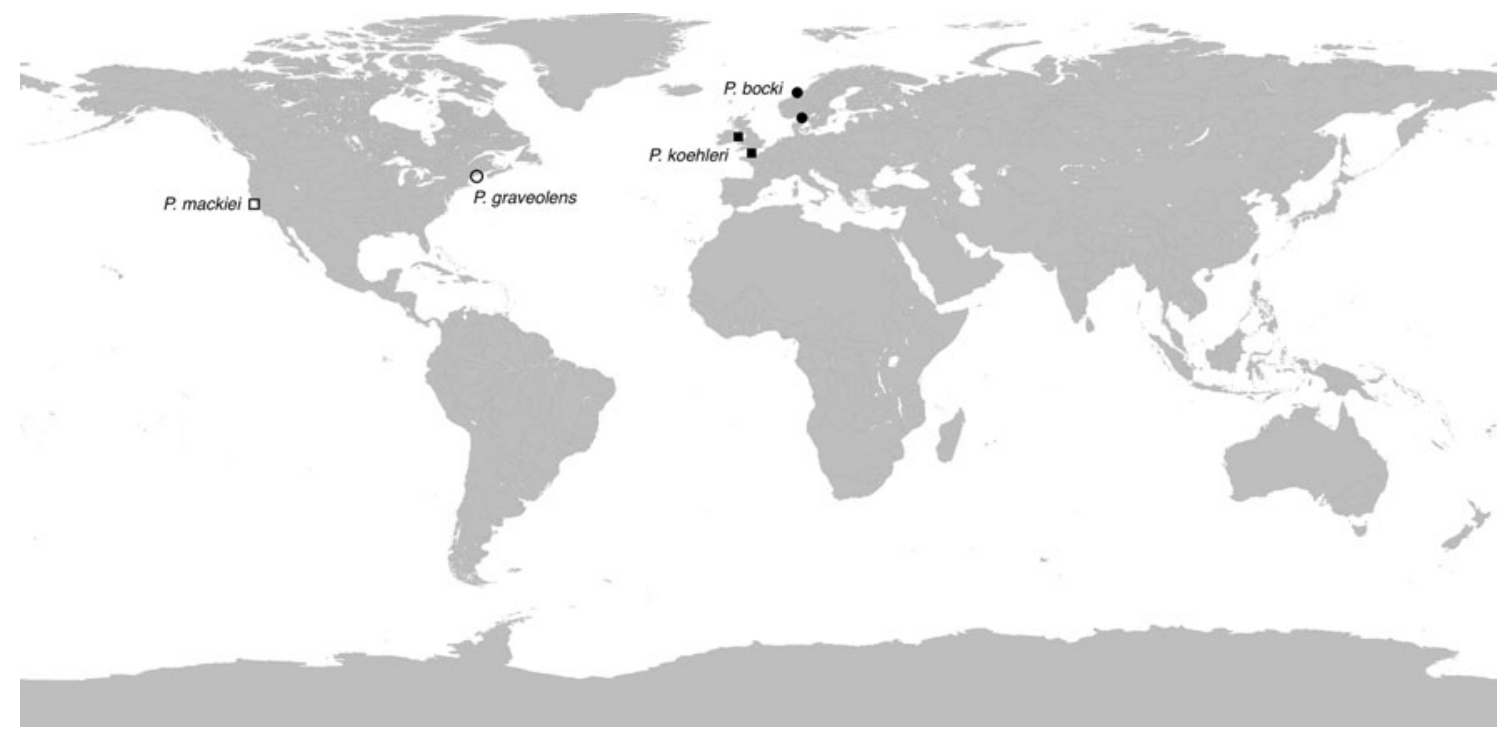

Fig. 18 The global distribution of all Protoglossus species, compiled from Caullery and Mesnil (1900, 1904), Burdon-Jones (1956), Giray and King (1996), Vogel (1987), and Deland et al. (2010)

Protoglossus are summarized in Table 2. The global distribution of all Protoglossus species is shown in Fig. 18.

Protoglossus koehleri resembles Protoglossus bocki, but there are clear differences in morphology, pigmentation and ecology. Detailed information on P. koehleri is given by Caullery and Mesnil (1900, 1904), van der Horst (1939), Burdon-Jones (1950a, b, 1956) and Vogel (1987). $P$. bocki is the smallest enteropneust species known, up to $1.5 \mathrm{~cm}$ total length, but $P$. koehleri is five times larger, up to $7.5 \mathrm{~cm}$. The body is clearly tapering in $P$. koehleri but of quite equal diameter or just very slightly tapering in $P$. bocki. The proboscis and collar are proportionally longer in $P$. koehleri than in P. bocki. The anterior rim of the collar is smooth or very slightly curled in $P$. bocki but more curled in $P$. koehleri. The proboscis skeleton differs from that of $P$. koehleri, particularly in its anterior parts (Fig. 14). This part has strongly developed wing-like pairs of dorsal and lateral projections in $P$. bocki, contrary to $P$. koehleri. The gills are proportionally larger, and the gill pockets are better developed in $P$. bocki than in $P$. koehleri. The gill pores are round in P. koehleri but elongated and transverse in $P$. bocki. The number of gill pairs can reach 17 in $P$. bocki but 50 in P. koehleri. The colours differ between both species. The proboscis is uniformly light pink to golden yellow in $P$. bocki but yellow with dark green spots in $P$. koehleri. The collar in $P$. koehleri is coloured like its proboscis, but the collar in $P$. bocki is white with transversal yellow bands. The proboscis stalk is light in $P$. bocki but dark green or dark brown in P. koehleri. The trunk is quite uniformly light golden yellow in $P$. bocki but contains much more pigmentation of different colours in P. koehleri. The gonad colour, however, probably does not have any important distinctive value, as similar colours are found in both species as well as in Harrimania kupfferi, white testes and red or rose ovaries. The species also differ in ecology. Protoglossus koehleri was described from a tidal canal with sand and stones at the French coast near Anse St. Martin (Caullery and Mesnil 1900, 1904). Also, BurdonJones (1956) collected his material from coarse sediment in the tidal zone. All the individuals of $P$. bocki have been sampled from sublittoral clay bottoms at a water depth of $30-150 \mathrm{~m}$.

The proportionally larger gills in $P$. bocki than in $P$. koehleri could be adapted to the different conditions in their respective environments. The larger $P$. koehleri lives in coarse sediment in shallow water. Water movements are normally intense in such environments, and the oxygenation of the water is good. On the contrary, $P$. bocki lives in fine, clayey sublittoral sediments. The water movements are usually slower, and the oxygenation is often limited. It would be an advantage with larger gills under such circumstances.

Protoglossus graveolens lives intertidally and is very much larger than $P$. bocki, up to $47 \mathrm{~cm}$. It has up to 142 pairs of gill pores and a different colouration. One of the most striking internal characters is that it has a large and well-developed dorsal mesenterium above its pericardium. The proboscis musculature is much more strongly developed and the protocoel proportionally smaller.

Protoglossus mackiei lives intertidally and is about twice as long as $P$. bocki. It differs in colour and in, for example, proboscis anatomy. Its dorsal mesenterium above the pericardium is very large, and the longitudinal 
Fig. 19 Phylogeny of Enteropneusta based on sequences of $18 \mathrm{~S}$ rRNA genes in GenBank and two newly sequences species (Protoglossus bocki n.sp. and Harrimania kupfferi). Remaining data from Cannon et al. (2009)

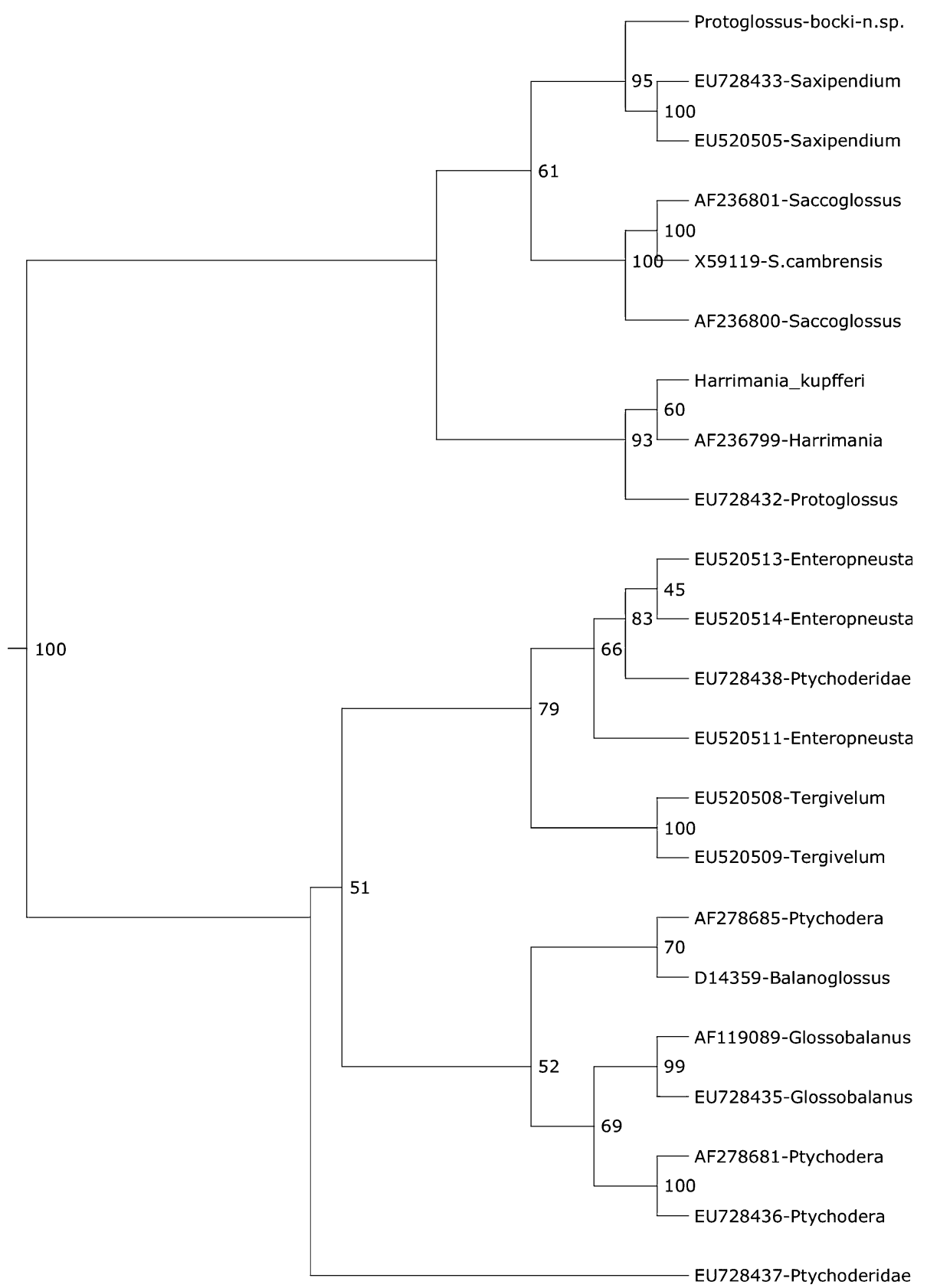

proboscis musculature strongly developed, so that only a very little protocoel is present.

Protoglossus bocki and P. koehleri show the largest similarities in general morphology, and both live in European waters. The size of the ovaries of the species $P$. bocki, $P$. graveolens and $P$. koehleri has been described. The ovary size is very large, which indicates that they have direct development without a pelagic tornaria larva. Species with this type of reproduction often have a limited ability to disperse and consequently also have a limited distribution. This also supports that they all are distinct species.

\section{Phylogeny}

A species called Protoglossus sp. collected in South Australia is included in an analysis by Cannon et al. (2009). The corresponding sequences in GenBank are, however, called Protoglossus koehleri. There are no morphological data available in order to make it possible to check the identity of this species. Species of the genus Protoglossus are described from the east and west coasts of North America and from Europe but never from Australia or the Indo-West Pacific region. The presumed limited dispersal ability of species of Protoglossus as well as Harrimania 
Table 2 Comparison of distribution, habitat and selected internal and external characters of diagnostic value within the genus Protoglossus (compiled from Burdon-Jones 1956; Giray and King 1996; Deland et al. 2010)

\begin{tabular}{|c|c|c|c|c|}
\hline & $\begin{array}{l}\text { Protoglossus bocki } \\
\text { n.sp. }\end{array}$ & $\begin{array}{l}\text { Protoglossus koehleri } \\
\text { (Caullery and Mesnil, 1900) }\end{array}$ & $\begin{array}{l}\text { Protoglossus graveolens } \\
\text { Giray and King, } 1996\end{array}$ & $\begin{array}{l}\text { Protoglossus mackei Deland } \\
\text { et al. } 2010\end{array}$ \\
\hline Distribution & $\begin{array}{l}\text { Boreal (Skagerak, } \\
\text { Norwegian Sea) }\end{array}$ & $\begin{array}{l}\text { Lusitanian (French Atlantic } \\
\text { coast, Irish Sea) }\end{array}$ & NW Atlantic, Maine, USA & $\begin{array}{l}\text { Pacific; Moss Beach, San } \\
\text { Mateo, California, }\end{array}$ \\
\hline Depth & $\begin{array}{l}\text { Sublittoral, } \\
30-150 \mathrm{~m}\end{array}$ & Intertidal & Intertidal & Probably intertidal \\
\hline Bottom type & Clay & Sand, gravel & Mudflat & Probably sand \\
\hline Max body length (mm) & c. 15 & 75 & 470 & 25 \\
\hline \# of gill pores & $9-17$ & $14-50$ & $>100$ & \\
\hline Proboscis colouration & $\begin{array}{l}\text { Uniformly light pink } \\
\text { to golden yellow }\end{array}$ & $\begin{array}{l}\text { Yellow with dark green } \\
\text { spots }\end{array}$ & Cream-white & White \\
\hline $\begin{array}{l}\text { Proboscis stalk } \\
\text { colouration }\end{array}$ & Light, whitish & Dark green or dark brown & & \\
\hline Collar colouration & $\begin{array}{l}\text { White with } \\
\text { transversal yellow } \\
\text { bands }\end{array}$ & $\begin{array}{l}\text { Yellow with dark green } \\
\text { spots }\end{array}$ & $\begin{array}{l}\text { Cream-white to orange- } \\
\text { brown }\end{array}$ & Yellow \\
\hline Trunk colouration & $\begin{array}{l}\text { Uniformly light } \\
\text { golden yellow }\end{array}$ & $\begin{array}{l}\text { Pigmentation of different } \\
\text { colours }\end{array}$ & $\begin{array}{l}\text { Branchial region } \\
\text { translucent } \\
\text { yellow to light yellow- } \\
\text { brown; } \\
\text { hepatic region brown; } \\
\text { intestinal } \\
\text { region pale yellow, fades } \\
\text { posteriorly }\end{array}$ & White \\
\hline $\begin{array}{l}\text { Dorsal mesenterium } \\
\text { above the pericardium }\end{array}$ & Absent & Well developed & Large and well developed & $\begin{array}{l}\text { Lower half large and well } \\
\text { developed, upper half tapering }\end{array}$ \\
\hline
\end{tabular}

makes it unlikely that the species from Australia is P. koehleri. The species mentioned as Protoglossus (EU728432) is located close to Harrimania (AF236799) in the analysis of Cannon et al. (2009) as well as in our analysis. We have also included the sequence of Harrimania kupfferi, previously not sequenced, that clusters as a neighbour of the former (Fig. 19). We regard the enteropneust from Australia as an undescribed taxon related to Harrimania. Protoglossus bocki, the only sequenced species of its genus, clusters close to the genus Saxipendium despite the morphological similarities with Harrimania (Fig. 19).

Acknowledgments Mrs. Karin Sindemark Kronestedt (NRM, Stockholm) identified, copied and sent parts of the archive of Sixten Bock. Mr. Christopher Reisborg (The Swedish Taxonomy Project) and Prof. Fredrik Pleijel (University of Gothenburg) kindly allowed us to use their colour photographs. Dr. Malin Strand supplied material that was sequenced at the Swedish Museum of Natural History, Stockholm, Sweden, by Prof. Ulf Jondelius, Ms. Karin Nilsson and Ms. Keyvan Mirbakhsh. Prof. Jan Pawlowski, University of Geneva, helped with the molecular analysis. Drs. Kristian Moller and Kennet Lundin as well as Professores emeriti Åke Franzén, Lars Orrhage and Bertil Åkesson are thanked for additional information. The Swedish Taxonomy Initiative financed expeditions (e.g. BIOSKAG) where additional material was sampled. Prof. K. Thomas Jensen helped with translation of parts of the French literature sources. Prof. em. Jørgen Hylleberg kindly commented the manuscript.

\section{References}

Benito J, Pardos F (1997) Hemichordata. In: Harrison FW, Ruppert EE (eds) Microscopic anatomy of invertebrates, vol 15, Hemichordata, Chaetognatha, and the invertebrate chordates. Wiley-Liss, Inc., New York, pp 15-101

Burdon-Jones C (1950a) An enteropneust genus new to the British Isles. Nature 165(4191):327

Burdon-Jones C (1950b) Records of British Enteropneusta. Nature 165(4199):636-637

Burdon-Jones C (1956) Observations on the enteropneust, Protoglossus koehleri (Caullery and Mesnil). Proc Zool Soc Lond 127:35-58

Cameron CB (2005) A phylogeny of the hemichordates based on morphological characters. Can J Zool 83:196-215

Cameron CB (2010) A comprehensive list of extant hemichordate species with links to images (your guide to 'global worming'). http://www.webdepot.umontreal.ca/Usagers/cameroc/MonDepot Public/Cameron/Species.html. Accessed 12 October 2010

Cannon JT, Rychel AL, Eccleston H, Halanych KM, Swalla BJ (2009) Molecular phylogeny of hemichordata, with updated status of deep-sea enteropneusts. Mol Phylogenet Evol 52:17-24

Caullery M, Mesnil F (1900) Sur une normale espèce de Balanoglossus (B. koehleri) habitant les côtes de la Manche. Compt rend hebd Séanc Mém Soc Biol Paris 52:256-259

Caullery M, Mesnil F (1904) Contribution à l'étude des Enteropneustes. Protobalanus (n. gen.) koehleri Caull. Et Mesn. Zool Jahrb Anat Ont Tiere 20:227-256 (pls 12-13)

Deland C, Cameron CB, Rao KP, Ritter WE, Bullock TH (2010) A taxonomic revision of the family Harrimaniidae (Hemichordata, 
Enteropneusta) with descriptions of seven species from the Eastern Pacific. Zootaxa 2408:1-30

Franzén $\AA$ (1956) On spermiogenesis, morphology of the spermatozoon, and biology of fertilization among invertebrates. Zool Bidr Upps 31:355-482

Franzén Å, Woodwick KH, Sensenbaugh T (1985) Spermiogenesis and ultrastructure of spermatozoa in Saxipendium coronatum (Hemichordata, Enteropneusta), with consideration of their relation to reproduction and dispersal. Zoomorph 105:302-307

Gerhart J, Lowe C, Kirschner M (2005) Hemichordates and the origin of chordates. Curr Opin Genetics Dev 15:461-467

Giray C, King GM (1996) Protoglossus graveolens, a new hemichordare (Hemichordata: Enteropneusta: Harrimanidae) from the northwest Atlantic. Proc Biol Soc Wash 109(3):430-445

Giray C, King GM (1997) Predator deterrence and 2,4-dibromophenol conservation by the enteropneusts Saccoglossus bromophenolosus and Protoglossus graveolens. Mar Ecol Prog Ser 59:229-238

Gonzalez P, Cameron CB (2009) The gill slits and pre-oral ciliary organ of Protoglossus (Hemichordata: Enteropneusta) are filterfeeding structures. Biol J Linn Soc 98:898-906

Gouy M, Guindon S, Gascuel O (2010) SeaView version 4: a multiplatform graphical user interface for sequence alignment and phylogenetic tree building. Mol Biol Evol 27:221-224

Hansson HG (2009) Marina sydskandinaviska "evertebrater"-ett naturhistoriskt urval. Preliminär (oillustrerad) utgåva. Göteborgs Universitet, Sven Lovén centrum för marina vetenskaper, Tjärnö. http://www.tmbl.gu.se/staff/HansGHanssonP.html. Accessed November 2009

Hejnol A, Obst M, Stamatakis A, Ott M, Rouse GW, Edgecombe GD, Martinez P, Baguña J, Bailly X, Jondelius U, Wiens M, Müller WEG, Seaver E, Wheeler WC, Martindale MQ, Giribet G, Dunn
CW (2009) Assessing the root of bilaterian animals with scalable phylogenomic methods. Proc R Soc B276:4261-4270

Hubendick B, Hyle G, Swärd S (1971) A Survey of the marine benthonic macro-fauna along the Swedish West Coast 1921-1938 By L.A. Jägerskiöld. Acta r Soc Sci Litt Gothobg Zool 6:1-146

Hyman LH (1959) The Invertebrates: Smaller Coelomate Groups Chaetognatha, Hemichordata, Pogonophora, Phoronida, Ectoprocta, Brachiopoda, Sipunculida. The coelomate Bilateria. McGraw-Hill Book Co., New York

Lindroth A (1941) Echiurida, Sipunculida und Enteropneusta aus dem Skagerak 1933. Zool Bidr Upps 20:443-453

Lundin K, Karlsson A, Möller P, Azurduy-Högström C, Andréasson E (2009) Faunistiskt nytt 2008-marina evertebrater. Göteborgs Naturhistoriska Musei Arstryck 2009:31-46

Meek A (1922) Glossobalanus marginatus, a new species of Enteropneusta from the North Sea. Quart J Microsc Sci 66:579594

Silén L (1950) On the nervous system of Glossobalanus marginatus Meek (Enteropneusta). Acta Zool 31:149-175

Théel H (1908) Om utvecklingen af Sveriges zoologiska hafsstation Kristineberg och om djurlifvet i angränsande haf och fjordar. Ark Zool 4(5):1-136 (5 pls, 2 maps)

van der Horst CJ (1939) Hemichordata. Bronns Klassen und Ordnungen des Tierreichs 4:I-XIII + 1-737

Vogel P (1987) Protoglossus koehleri (Hémichordés, Enteropneustes) dans l'Aber de Roscoff. Cah Biol Mar 28:225-229

von Willemoes-Suhm R (1871) Biologische Beobachtungen über niedere Meeresthiere. 4. Über Balanoglossus Kupfferi aus dem Oeresund. Zeitschr wiss Zool 21:380-396 